\title{
(DES)SILENCIANDO OS RASTROS DA MARUJADA DE SÃO BENEDITO EM CRÔNICAS DA REVISTA BRAGANÇA ILUSTRADA
}

\author{
Larissa Fontinele de ALENCAR ${ }^{1}$
}

RESUMO: Propõem-se a análise das crônicas "O Esperado" de Lobão da Silveira e "O Chamado" de Jorge Ramos, ambas publicadas na década no ano de 1952, na revista Bragança Ilustrada, a partir da suposição do silenciamento de rastros reminiscentes ao período de escravidão dos negros e à religião afrodescendente no Brasil, que produzem múltiplos indicadores de uma resistência silenciosamente observada em códigos literários que omitem as evidências de uma cultura originariamente africana sincretizada com o catolicismo dominante na época do Brasil-Colônia. Deste modo, ressaltaremos estudos do rastro e do silêncio, assim como uma breve discussão teórica sobre a memória, dialogando com uma abordagem etnográfica sobre a Marujada de São Benedito de Bragança-Pa para, em seguida, analisarmos as crônicas.

Palavras-chave: Silêncio. Resistência. Marujada.

ABSTRACT: We propose the analysis of chronic "O Esperado" by Lobão da Silveira and "O Chamado" by Jorge Ramos, both published in the decade in 1952, in the magazine Bragança Ilustrada, on the assumption the silencing of tracks reminiscent of the period of slavery black and religion of African descent in Brazil, which produce multiple indicators of resistance silently observed in literary codes which omit evidence of a culture originally syncretized with African Catholicism dominant in the era of colonial Brazil. Thus, we will highlight studies of the trail and silence, as well as a theoretical discussion about memory, dialoguing with an ethnographic approach about the Marujada de São Benedito from Bragança-Pa, and then analyzes the chronicles.

Keywords: Silence. Resistance. Marujada. 
Fig. 01: Vista da orla cidade de Bragança-PA

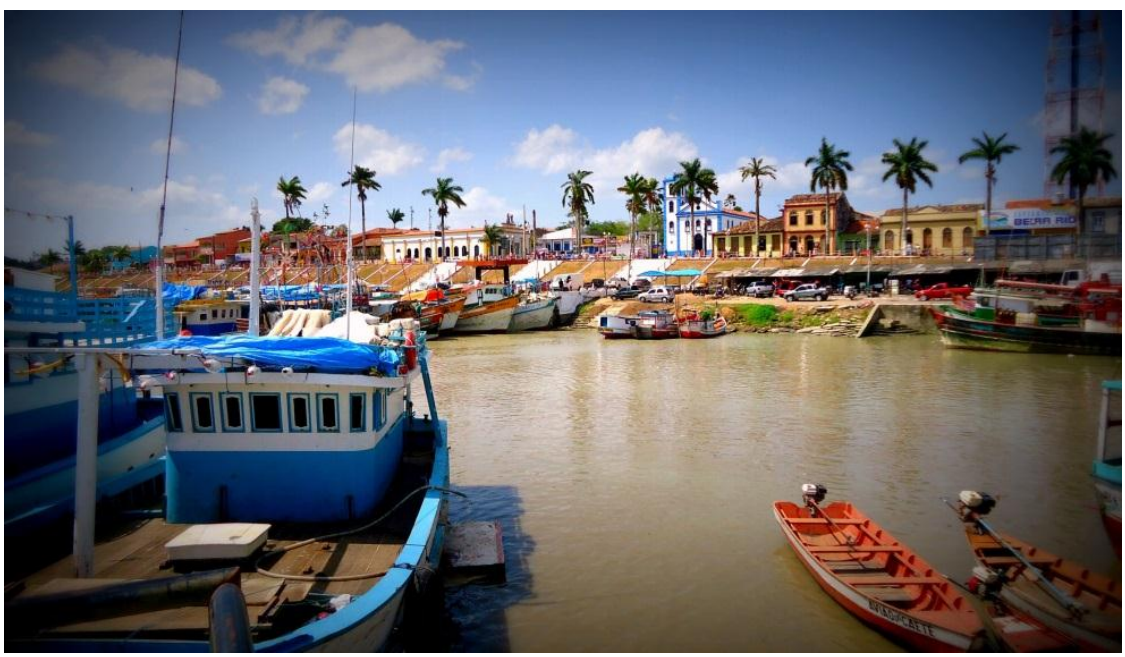

Fonte: Acervo Pessoal. Dezembro/ 2012.

Este artigo tem como objetivo identificar e analisar os sentidos dos rastros silenciosos da resistência negra presentes na Marujada de São Benedito de Bragança, Pará, mais especificamente nas crônicas "O Esperado", autoria de Lobão da Silveira e "O Chamado" de Jorge Ramos, publicada originalmente na década de 1950, na revista Bragança Ilustrada. Para esta análise lançamo-nos nas discussões sobre duas categorias produtoras de sentido: a memória e o silêncio. Destacando a ausência do elemento negro, em sobreposição de características de exaltação do povo e da cultura.

É necessário explicitar que a Festividade do Glorioso São Benedito, Marujada de Bragança, originou-se da iniciativa de negros no ano de 1798 ao fundarem a Irmandade em louvação ao "Santo Preto", e partimos do princípio de que a origem que remonta a Escravidão brasileira está silenciada em grande parte das narrativas literárias bragantinas. Por isso, faremos um breve levantamento de alguns dados históricos importantes para a compreensão da proposta analítica.

É, portanto, nesse sentido que nos enveredamos pelas matas silenciosas e vastas da memória que nos levaram até o altar do Santo Preto de Bragança, da bela Marujada de chapéu de fitas coloridas e de pés descalços que fixam as suas pegadas nas ruas históricas de cidade, deixando os rastros para serem, quiçá, dessilenciados.

\section{A Marujada de São Benedito em Bragança - Pará.}

Fig. 02: Marujas pelas ruas da cidade de Bragança-PA 


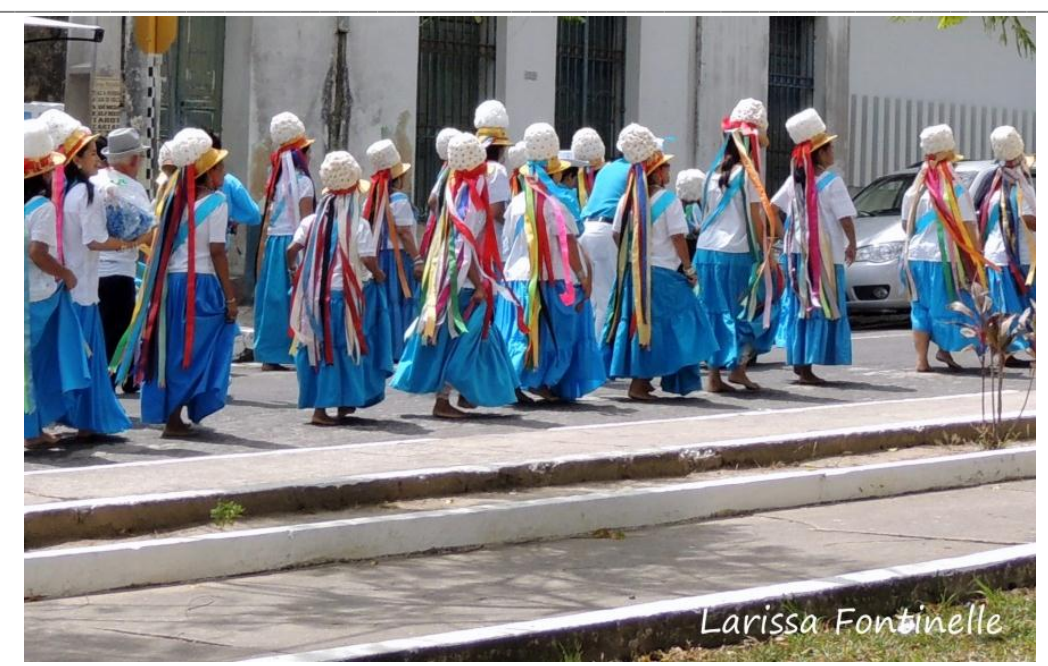

Fonte: Acervo Pessoal. Dezembro/ 2012.

Bragança é uma das cidades mais antigas do estado do Pará, muito antes dos franceses da expedição de La Ravardière, comandados por Daniel de La Touche, passarem por essas plagas, por volta de 08 de julho de 1613, e os portugueses assentarem as famílias açorianas, por volta de 1677 , quem habitava a região era a nação indígena dos Caetés, da grande tribo Tupinambás que habitava boa parte do Brasil, précolonial.

Essas raízes históricas de Bragança remontam ao início da colonização portuguesa no Pará, entre os séculos XVIII e XIX, a região era considerada um território promissor devido sua localização estratégica e conexão fluvial com o Maranhão, o que propiciava a entrada e comércio clandestino de escravos. De acordo com a pesquisadora Edna Castro:“[...] Bragança desempenhou um papel relevante na formação da sociedade regional. Nela ecoam ainda vozes dos pretos velhos que contam as histórias de quilombos e aquilombados da mata, das condições impostas ao negro na sociedade colonial, e de resistências" (2006, p. 11).

O índio, o branco e o negro são os elementos étnicos que formam a população bragantina, com seus hábitos culturais. Não só da miscigenação, mas principalmente da iniciativa dos escravos surge o culto ao São Benedito, santo negro católico, para a formação de uma das maiores festividades do estado do Pará, a Marujada de São Benedito, uma manifestação cultural e religiosa repleta de símbolos que remetem tanto a religião católica quanto ao fervor das suas origens africanas.

De acordo com Carvalho (2010), a origem da Marujada remonta ao ano de 1798, no auge da Escravidão no Brasil, mais especificamente a 03 de setembro, dia em que os senhores permitiram que 14 escravos formassem a Irmandade do Glorioso São Benedito 
de Bragança. Com a autorização, os escravos percorreram as ruas da cidade e dançaram em frente às casas dos seus senhores em forma de gratidão. Nos anos seguintes, os escravos repetiram o trajeto e fizeram novos agradecimentos, consolidando a tradição de louvação ao São Benedito com o entrelaçamento da dança e música afrodescendente envolvendo o ritual aparentemente católico. Assim, surgiu a Marujada com a implementação da Irmandade do Glorioso São Benedito de Bragança (IGSBB), como uma forma de resistência cultural, frente ao atrelamento e sujeição dos "irmãos" ao seu amo e ao clero católico.

É importante ressaltar, o contexto sociocultural em que a Marujada foi fundada, como bem observa Carvalho (2010, p. 68):

Como em todo o Brasil Colônia, a região do Caeté foi marcada pelo genocídio de incontáveis populações/tribos autóctones. Posteriormente, a escravidão do negro trazido da África para aquela região irmanou o sofrimento e angústia de índios, negros e mestiços.

A resistência dos escravos se inicia na concepção da Irmandade do Glorioso São Benedito, mantidas suas peculiaridades culturais sob um véu de religião cristã, o que demarcava a aceitabilidade dos senhores, mas encobriam as práticas afro religiosas. A Marujada surge como uma forma de resistência cultural, frente ao atrelamento e sujeição dos "irmãos" ao seu amo e ao clero católico, refletido na implementação da Irmandade do Glorioso São Benedito de Bragança. Conforme Nonato da Silva (2006, p. 16):

\footnotetext{
A organização não somente da Irmandade do Glorioso São Benedito de Bragança, em 1798, mas de diversas outras confrarias leigas, como arma de resistência, cuja preservação de certo arcabouço cultural garante várias permanências até hoje perceptíveis e que seus agentes fundadores, considerados "subumanos" - para os brancos senhores, as brancas madames e a Lei dos brancos -, desqualificados para o trabalho da agroindústria que chegara com o tempo, sem terras ou educação primária, mantiveram-se presos às relações sociais caracterizadas pela dependência com relação ao senhor e ao clero católico.
}

Podemos observar que a tática utilizada pelos negros promovia a organização e escolha de lideranças sob a proteção do manto do Catolicismo, por sua vez os senhores utilizavam como uma estratégia política, já que temiam as ameaças crescentes das revoltas dos escravos e as fugas para os quilombos, por isso conceder aos negros a oportunidade de promover uma grande confraternização entre si, promoveria também o apaziguamento e evidenciava a "bondade" dos senhores, que agora seriam tratados como benfeitores, esse é o discurso hegemônico que ainda é propagado e prevalece nos informativos históricos, distribuídos anualmente em decorrência da festividade, que são 
confeccionados pela Irmandade da Marujada de São Benedito, visto que mencionam: "os negros em sinal de reconhecimento e agradecimento, foram dançar de casa em casa dos seus benfeitores",

Portanto, a identidade negra da época do Brasil-Colônia e a identidade dos colonizadores se entrelaçam silenciosamente constituindo uma malha fina de conexões culturais, que se imbricam complexamente, formam a principal representação da identidade do povo bragantino. Fé e devoção ao santo católico, que em sua raça negra traduz a memória dos afrodescendentes, refletida nas danças, nas cores, nos trajes, nos pés descalços das marujas, nos instrumentos de percussão e na música, elementos cuja presença atualmente ainda pode ser observada durante a Festividade da Marujada de Bragança.

\section{Bragança Ilustrada: Os rastros de Lobão da Silveira e Jorge Ramos}

A partir de 1908, Bragança passa por um despertar sociocultural advindo do desenvolvimento decorrente da implementação da estrada de Ferro que escoava a produção das agrovilas colonizadas por espanhóis e nordestinos, principalmente a Vila de Benjamim Constant, para a capital do estado. O desenvolvimento da cidade era crescente: imprensa local com grande disseminação, muitas motivações políticas, intelectuais se interessavam pela cultura bragantina, enfim a cidade cresceu não só em dimensões como em reconhecimento cultural no cenário paraense. A Bragança da década de 1950 chegou ser considerada a segunda cidade do estado, sendo a primeira a capital- Belém.

Em decorrência de tudo isso, de acordo com Ubiratan do Rosário (2006), o apogeu da intensificação da vida social bragantina ocorreu na década de 1950 e princípios da década de 1960. O professor Ubiratan do Rosário denomina este período de "Lobão da Silveira", devido tratar-se de uma figura eminente no cenário político paraense e de grande influência na sociedade bragantina.

Lobão da Silveira (1910-1975) era jornalista, professor e advogado por formação profissional, mas se destacou como exímio político com três mandatos de prefeito, um de deputado estadual e outro de federal e, por fim, na década de 60, como senador federal por dois mandatos. Era a voz bragantina no congresso, que clamou em vão pela não interrupção da Estrada de Ferro e, ação que trouxe como consequência, a decadência socioeconômica do município. Em vão, pois "o sonho foi interrompido 
bruscamente com o golpe da Estrada de Ferro em 1966" (ROSÁRIO, 2006, p. 39), o sonho de desenvolvimento pleno e contínuo a partir da expansão ferroviária.

Antes, Lobão da Silveira concepcionou e financiou a revista Bragança Ilustrada, juntamente com Jorge Ramos, Eimar Tavares entre outros intelectuais elaboraram uma revista que mesmo em limites bragantinos pudesse abordar temas de cunho universal e pudessem alcançar leitores em todo o estado do Pará.

Assim como Lobão da Silveira, Jorge Ramos era advogado com inserções na política, foi eleito prefeito e deputado estadual, dedicou-se a escrita, seja literária em formas de poemas, contos e crônicas seja jornalísticas em suas reportagens com grande repercussão nos meios sociais de Bragança e região, chegando a atuar em jornais como O Estado do Pará e O Liberal, ambos da capital do Estado.

Mas foi em sua produção poética que Jorge Ramos propaga apaixonadamente o amor à sua terra natal, ao reverencia-la através de personagens que povoaram sua memória, seus amores e devaneios mais profundos traduzidos na sensibilidade dos poemas. Frequentemente lembrado como o criador do neologismo bragantinidade em seus poemas de louvação à Marujada de Bragança, mas que principalmente identificavam o povo unido por um sentimento que emanava no lirismo de sua poesia.

Tanto Lobão da Silveira quanto Jorge Ramos participaram ativamente do aparato intelectual da revista Bragança Ilustrada, o primeiro exercia a função de diretor, o segundo a função de secretário. Além de publicarem massivamente seus textos, sejam reportagens sejam literários.

De acordo com o Ubiratan do Rosário (1999), a revista Bragança Ilustrada surgiu a partir de momentos de inspiração em reuniões de intelectuais bragantinos e belenenses no Café Albano, reuniões denominadas TABA. A revista primava pela diversidade dos assuntos abordados que iam desde o existencialismo filosófico de Jean Paul Sartre, passando por amenidades sociais que esboçavam as jovens bragantinas, até chegar às narrativas e poemas sobre a terra banhada pelo Rio Caeté, o principal enfoque do periódico.

A revista Bragança Ilustrada circulou no período de 1950 até 1954, o início de uma década de pós-guerra, com seus anseios de paz e mudança, prosperidade e desenvolvimento, tão almejados na época. Como diz Ubiratan do Rosário (1999, p. 9): "Essa ideologia de paz está eloquente na Bragança Ilustrada, revista trimestral (às vezes semestral) de cultura, proposta por seus dirigentes, a ultrapassar [...] os limites do 
município e do estado, para tornar-se uma revista 'por Bragança, pelo Pará e pelo Brasil"".

Pode-se notar a importância da revista para a sociedade e a relevância dos temas abordados, a grande aceitação do público fez com que ela alcançasse proeminência em todo estado, chegando a publicar contos e crônicas de grandes escritores brasileiros como Graciliano Ramos e Euclides da Cunha.

Ainda conforme nos diz Ubiratan Rosário (2006, p. 38)

O apogeu na década de 50, vertigem do despertar propiciado pela ferrovia, é aureolado e simbolizado na fulgurante revista cultural, literária e acadêmica: Bragança Ilustrada mais o longevo Jornal do Caeté, marcos da projeção cultural e econômica e política de Bragança, [...]

Portanto, não se pode negar que a Bragança Ilustrada é o marco da década de 50, a divulgação dos escritores das terras caeteuaras com suas temáticas de exaltações à Bragança projetaram uma sociedade emergente bragantina de belas jovens, de grandes intelectuais e de cultura rebuscada.

\section{Os rastros: fitas do silêncio no chapéu da memória}

As marujas bragantinas levam na cabeça um dos mais significantes símbolos da cultura da Marujada: o chapéu feito de pequenas flores de penas brancas e lantejoulas douradas ao centro e nas bordas uma gama de cores em fitas, pendendo ao chão, dando vibração e movimento. Apropriaremos da metáfora para identificarmos a memória enquanto linguagem, enquanto palavra dita ou silenciada em matizes de tantas cores, de tantos discursos, como as fitas que decaem do chapéu, umas aparecem mais que as outras, de longe parecem unas, mas são distintas em sua complexidade tons e tamanhos.

Ao percorrer os caminhos da memória, nos deparamos com conceituações sobre a ideia do que seria o rastro, muito além das definições simplórias que o delimitam como vestígios deixados por uma pessoa ou animal ao rastejar-se pelo chão, pegadas. De fato, rastro são marcas, mas para muito além das pistas inscritas surgem as pistas silenciosas, o "não-dito" que precede um relance de significação, tudo é rastro, portanto, passível de ter sentido.

Ao nos apropriarmos do conceito de rastro, enquanto metáfora da memória, que elucida Jeanne Marie Gagnebin em seu artigo "O rastro e a cicatriz: metáforas da memória" observaremos que a escrita é sim um rastro, mas no sentido de que foi deixado aleatoriamente, "sem intenção prévia, que não se inscreve em nenhum sistema codificado de significações, que não possui, portanto, referência linguística clara", pois 
quem deixa rastros, não faz com finalidade de transmitir uma significação, "é fruto do acaso, da negligencia, às vezes da violência; deixado por um ladrão em fuga, ele denuncia uma presença ausente- sem, no entanto, prejulgar sua legibilidade" (GAGNEBIN, 2006, p. 113).

Nesse sentido, a autora nos chama atenção para o deslize com que o rastro foi deixado, são pistas jogadas no vento, portanto, os decodificadores do rastro também trabalham sempre em um processo de desvendar, adivinhar, como nos diz:

O detetive, o arqueólogo e o psicanalista, esses primos menos distantes do que pode parecer à primeira vista, devem decifrar não só o rastro na sua singularidade concreta, mas também tentar adivinhar o processo, muitas vezes violento, de sua produção involuntária. Rigorosamente falando, rastros não são criados - como o são outros signos culturais e linguísticos -, mas, sim, deixados ou esquecidos. (GAGNEBIN, 2006, p.113)

Em meio a esse desenrolar de rastros sobre rastros, a autora recorre ao filósofo Emmanuel Lèvinas para ressaltar, em outro contexto, a diferença entre o signo e o rastro. E assim, enfatizar ainda mais que o rastro é um signo aleatório e não intencional, logo, totalmente desprovido de intenção significativa. Vejamos o que nos diz Lèvinas:

O rastro não é um signo como outro. Mas exerce também o papel de signo. Pode ser tomado por um signo. $\mathrm{O}$ detetive examina como signo revelador tudo o que ficou marcado nos lugares do crime, a obra voluntária ou involuntária do criminoso; o caçador anda atrás do rastro da caça; o rastro reflete a atividade e os passos do animal que ele quer abater; o historiador descobre, a partir dos vestígios que a existência das civilizações antigas deixou, como horizontes de nosso mundo. Tudo se dispõe em uma ordem, em um mundo, onde cada coisa revela outra ou se revela em função dela. Mas, mesmo tomado como signo, o rastro tem ainda isto de excepcional em relação a outros signos: ele significa fora de toda intenção de significar [de faire signe] signo e fora de todo projeto do qual ele seria a visada. [...] $\mathrm{O}$ rastro autêntico [...] decompõe a ordem do mundo; vem como em 'sobreimpressão'. Sua significância original desenha-se na marca impressa que deixa, por exemplo, aquele que quis apagar seus rastros, no cuidado de realizar um crime perfeito. Aquele que deixou rastros ao querer apagá-los, nada quis dizer nem fazer pelos rastros que deixou. Ele decompôs a ordem de forma irreparável. Pois ele passou absolutamente. Ser, na modalidade de deixar um vestígio, é passar, partir, absolver-se. (LÈVINAS, 1993, p. 75-76 apud GAGNEBIN, 2006, p. 113).

O rastro possui uma significância original, parte de um princípio, algo surgiu ou aconteceu para que o indício aparecesse, a marca impressa é o resultado de um acontecimento, para o ladrão o furto, para o assassino a morte, para o caçador as pegadas do animal, para o historiador os sinais complexos da existência humana. Na tentativa de apagar uma marca outras tantas surgirão. Como a própria autora elucida o exemplo de um ladrão que ao querer apagar seus rastros acaba por deixar outros tão incisivos quanto os primeiros. E como, mostra Lèvinas, para realizar o crime perfeito 
apaga-se os rastros, pois nada quis dizer, o significado não pode ser revelado, a ordem é decomposta, e o rastro original já não existe mais, é absolvido pelo próprio ser.

Já ao nos depararmos com a condição silenciosa do rastro, passamos a percorrer um caminho teórico para pensarmos o silêncio, enquanto teor significante da linguagem. Desta forma Orlandi (1997) elucida que o silêncio é fator principal, como a própria condição do significar, há um modo de estar em silêncio que equivale a um modo de estar no sentido. E assim, a condição humana em seus processos discursivos "percebeu o silêncio como significação, criou a linguagem para retê-lo.” E se silêncio é linguagem, estabelecem-se as possibilidades de sentidos que transparecem com a interpretação, afinal “as palavras são múltiplas, mas os sentidos também o são.” (ORLANDI, 1997, p. 29).

Nesse texto sobre as formas do silêncio, Orlandi propõe distinguir entre o silêncio fundador e o silenciamento. Esse último, por sua vez, é a política do sentido e, por isso, faz parte da retórica da dominação (a da opressão), assim como do seu avesso, a retórica do oprimido (a da resistência). Mas não é suficiente pensar só o silenciamento, "para compreender a linguagem é preciso entender o silêncio para além da sua dimensão política” (ORLANDI, 1997, p. 31).

E nesse ponto, ressalta-se o silêncio fundante, ou seja, "o real da significação é o silêncio". A palavra gira em torno do silêncio, os sentidos só se fazem a partir da linguagem, deve-se entender que o silêncio é, sobretudo, parte significante fundamental para o entendimento do discurso. Afinal. "o homem está condenado a significar. Com ou sem palavras, diante do mundo, há uma injunção à "interpretação": tudo tem de fazer sentido (qualquer que ele seja)" (ORLANDI, 1997, p. 32).

O silêncio assume diferentes formas. De acordo com Orlandi, devemos distinguir conceitos que estão próximos, mas são provenientes de natureza diversa, um desses pontos é a distinção entre o silêncio e o implícito. Ao se tratar de linguagem, podemos cair na simplificação de discorrer sobre o silêncio da mesma maneira que pensamos o subentendido, o dito que remete ao não-dito. Quanto a isso, Orlandi (1997, p. 68) elucida que o silêncio "não remete ao dito, ele se mantém como tal, ele permanece silêncio e significa". Em suma, o silêncio não recobre o mesmo campo do implícito e não é transparente, assim como a linguagem. Sendo assim, "o silêncio não tem uma relação de dependência com o dizer para significar: o sentido do silêncio não deriva dos sentidos das palavras." (ORLANDI, 1997, p. 68). 
Por esse motivo, a importância de não esquecer que o silêncio funda o significado, permitindo o movimento plural dos sentidos, que não ocorrerá apenas na omissão de palavras. E como já mencionamos, a política do sentido é o silenciamento composto por um silêncio constitutivo, que pertence à própria ordem de produção do sentido, e pelo silêncio local, que é a interdição do dizer, como expõe Orlandi (1997, p. 75): "a diferença entre o silêncio e a política do silêncio é que a política do silêncio produz um recorte entre o que se diz e o que não se diz, enquanto o silêncio fundador não estabelece nenhuma divisão: ele significa em (por) si mesmo".

Partindo da ideia de silêncio no discurso, enveredar-nos-emos pelas trilhas da memória, do esquecimento e do silêncio, como faz Michael Pollak (1989), para reforçar a ideia de silêncio na memória. Pollak enfatiza o jogo entre as memórias coletivas e individuais, por questão de enquadramento uma acaba por sobrepor a outra e manter o silenciamento diante de um discurso hegemônico, no entanto a "subversão no silêncio e de maneira quase imperceptível afloram em momentos de crise em sobressaltos bruscos e exacerbados" (1989, p. 04) a fronteira do dito e o não dito é tênue, e quando tensionadas, se deixa escapar provocando os sentidos do silêncio.

São sobreposições, enquadramentos, doutrinação ideológica que cerceiam a memória coletiva de tal forma que para ser ouvida é necessário estar em silêncio, e não ser levado ao esquecimento, muito pelo contrário transmuta-se em resistência.

E assim, "existem nas lembranças de umas e de outras zonas de sombra, silêncios, 'não-ditos'. As fronteiras desses silêncios e 'não-ditos' com o esquecimento definitivo e o reprimido inconsciente não são evidentemente estanques e estão em perpétuo deslocamento" (POLLAK, 1989, p. 08). Em outras palavras, são dinâmicos e estão em eterna relação, não se separa com uma régua, pois estão imbricados a ponto de um ser o outro: o que um diz, revela o outro silenciado.

Os personagens e os tempos mudam, mas os rastros mostram que os silêncios perduram e traspassam a história. Portanto, se queremos observar uma tradição cultural secular como a Marujada de São Benedito de Bragança, devemos ressalvar quais são os rastros e os silêncios que se instauram tanto na história quanto nas narrativas literárias. Por isso que se torna tão necessário ressaltar as crônicas que foram veiculadas nos jornais e revistas da região. Sendo assim, partimos para a observação minuciosa na iniciativa de descobrir os índices que marcam a identidade bragantina revelada nas relações com a Marujada de São Benedito, assim como, os rastros silenciados nas crônicas. 


\section{“O Esperado" e "O Chamado": rastros silenciosos da Marujada de Bragança.}

É da memória que paira nos discursos das crônicas: "O Esperado" de Lobão da Silveira e "O Chamado" de Jorge Ramos, pulicadas na Revista Bragança Ilustrada em dezembro do ano de 1952, que observaremos os ditos e os não-ditos. A tarefa é capturar os discursos silenciosos ou silenciados que entrelaçam a memória, o que leva o sujeito a dizer silenciando através de três eixos temáticos: as esmolações, as representações da Marujada e os silêncios da identidade negra, como veremos nos tópicos a seguir:

\section{As esmolações: sons do chamado silencioso}

Fig. 03: Saída das Esmolações.

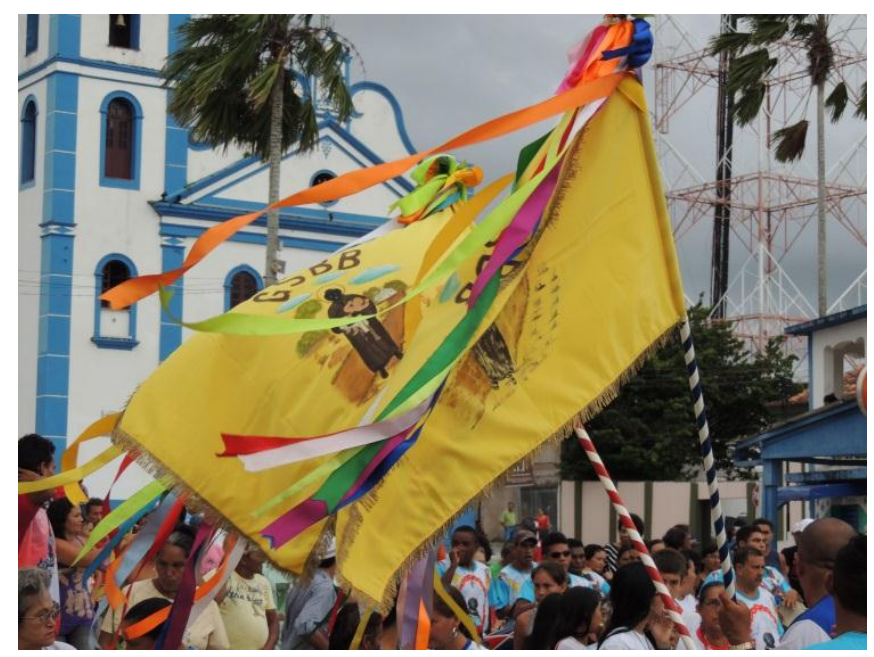

Fonte: Acervo Pessoal. Abril de 2013.

O texto de Lobão da Silveira inicia com as referências ao princípio da festividade da Marujada, alguns meses antes da festa propriamente dita, as esmolações, que nos tempos atuais iniciam no mês de abril, vejamos: "Faz um mês que os tan-tans dos tambores e o ruído da onça avisam que São Benedito está nas esmolas. E o som desses instrumentos atravessa rios, corta estradas, penetra lares, na prática que o tempo não consegue destruir." (SILVEIRA, 1952, p. 78). A menção às sonoridades é clara, as esmolações são os cortejos dos promesseiros que percorrem nos interiores de Bragança carregando imagens de São Benedito, com o intuito de arrecadar donativos para a festa, assim como divulgar o louvor ao santo.

O anúncio de que o santo está passando nas comunidades se dá através do som dos instrumentos musicais: reco-reco, pandeiro, onça e tambores. Quando retumbares típicos dos esmoladores soam ao longe, é sinal que o santo está por perto, é hora de 
preparar as doações. O caminho é extenso, o som dos tan-tans, através dos esmoladores, percorrem longas jornadas no rastro das tradições "que o tempo não consegue destruir". Destaque para a palavra "destruir" que em sua carga semântica, revela a eminência do aniquilamento através do tempo que revela uma possibilidade de apagamento de uma memória. O próprio discurso do narrador, silencia outra história de apagamento que não é temporal, é política, é o silenciamento de uma cultura afrodescendente pelos senhores brancos. Silenciam-se essas possibilidades: seria somente o tempo que tentou destruir a esmolação? Ou também o clero, que em tempos hodiernos a crônica, tentou por muitos anos extinguir a prática dos esmoleiros. São os silêncios que ficam no ar, sinais da resistência dos oprimidos mediante a imposição seja do tempo e suas modernidades, seja do branco intelectual e suas crenças e descrenças.

Deste modo, os promesseiros seguem no seu ofício sagrado, obrigação de esmolar e missão de manter a tradição: "Vão passando os esmoleiros na sua missão. Arrecadam aquilo que a boa vontade da nossa gente lhes dá. Tudo vem.” (SILVEIRA, 1952, p. 78). Há a valorização da esmola, qualquer doação tem importância, mas o que ressaltará é a demarcação do desejo, dá-se não porque se impõe, mas porque se quer dá, e o mais interessante é os tipos de esmolas: a galinha gorda, o pato roliço, o peru avantajado, o franguinho que muda as primeiras penas, o molho de fumo preparado com todo carinho da melhor folha, o poldro que escapou da morte, a farinha gostosa feita da mandioca amarelinha, o garrote que não morreu de sede, o pé de cravo que vem das praias, o crisântemo cultivado no girau, a catinga de mulata e pitombas tão típicas da época. Dá-se o que se tem no quintal ou que ainda restou nele, tira-se do que é da sustentabilidade da família para prestar a sua colaboração com a festividade. Cada elemento representará a família do devoto. Cada esmola ofertada será a representação do povo lavrador dos campos, das praias e das colônias, são símbolos silenciosos que remetem as bases da tradição cultural de uma festa feita pelos menos abastados, afinal quem sustenta a festa são os "desvalidos", assim como os escravos do princípio.

"Tudo é dado de bom gosto. E, por isso tudo dá dinheiro. Ninguém regateia preço, é p'ra São Benedito." (SILVEIRA, 1952, p. 78). Os mais pobres dão o que possuem de melhor no terreiro, sua produção, é símbolo da contribuição, se não pode doar dinheiro, doa-se o que tem de melhor, se só restou o poldro e o garrote são eles que irão como donativos, afinal são para o santo. E no fỉm, todas as doações se transformarão em dinheiro, pois são vendidas por um bom preço. Quando se trata de São Benedito, doa-se o que tem de melhor e compra-se no valor acima da média, não se 
deve escassear, muito menos pechinchar, pois assim como o santo faz milagres, ele também pode castigar, então não se deve menosprezar os donativos e comprar a qualquer custo, pois a esmola do santo é valiosa, mesmo sendo de origem humilde.

Em contrapartida aos aspectos concretos da esmolação de São Benedito que antecede a Festa da Marujada, na crônica "O Chamado" de Jorge Ramos acontece um enaltecimento do encantamento emocional provocado pelas sonoridades dos tambores ritmados do retumbão que cadenciam chamando o povo das comunidades longínquas da sede do município. Ouve-se o som, não se sabe de onde vem, é o grande mistério, os compassos que lembram o santo fazem-se ouvir em terras ainda mais distantes, estranhas:

\footnotetext{
Não se sabe bem como se ouve o chamado. Nem nunca se saberá. É um mistério da alma humana, tão grande como os outros que por aí existem. Acontece que um bragantino que se preza, já recebeu o chamado em muitas épocas do ano, porém mais se acentua neste último mês, que dezembro é o mais bragantino dos meses. Está no trabalho, pensando nos seus negócios, longe da terra, seja em Belém, em Pekin ou New York, ou onde seja, metido, coitado entre cifras e eis que de repente começa a ouvir o estranho chamado. Isso seja ele médico, advogado, comerciante, jornalista, industrial ou de qualquer profissão[...]. (RAMOS, 1952, p. 3)
}

O mais notável nesse excerto da crônica é a demarcação das cidades e das

profissões dos que ouvem o chamado, em grandes capitais ou de profissões de classe elitizada. O chamado soa para o bragantino das classes abastadas, que saiu da sua terra natal para profissionalizar-se, em contrassenso com o bragantino que originou e vivencia a Marujada nas terras distantes de Bragança. Seria, portanto, o chamado o som que ecoa para todos, sem distinção de classe.

Diferentemente da crônica de Lobão da Silveira, "O Chamado" ecoa silenciosamente na memória do bragantino abastado e afastado dos rituais. Os ecos do chamado se propagam através do calendário, ao olhar para a data o bragantino acha tudo ao seu redor sem graça e só a Marujada se faz alegre, pleno de saudade, o 26 de dezembro é o dia da grande festa, do alvoroço e da louvação, das marujas em fila e dos amigos que se reúnem em torno da igreja, da contemplação e da diversão.

\section{As representações da festa da Marujada como um elemento unificador da cultura}

Fig. 04: Procissão de São Benedito 


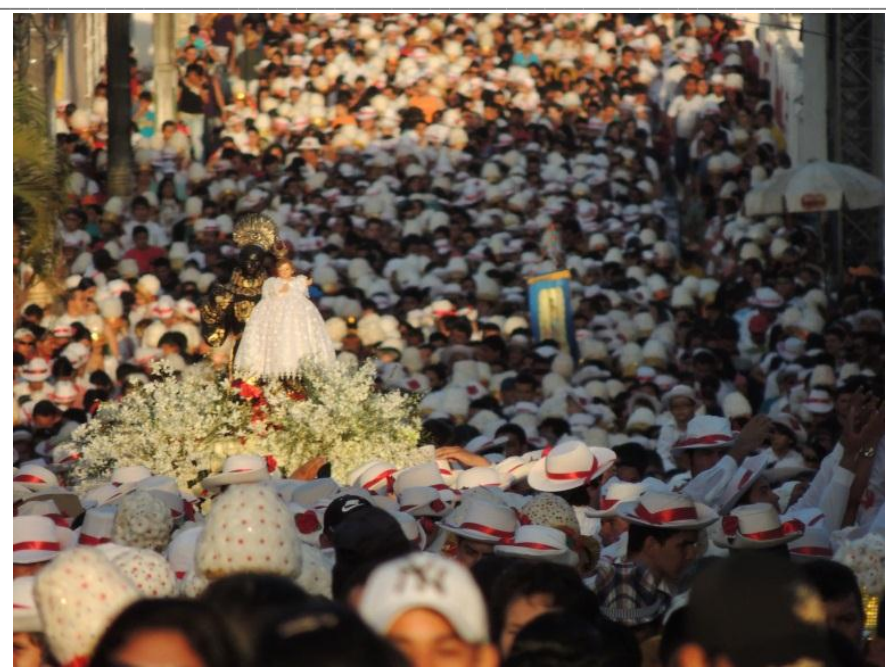

Fonte: Acervo Pessoal. Dezembro de 2012.

Ao fim das esmolações, iniciam os festejos. E assim, "As marujas se enfeitam. Saias encarnadas e azuis. Blusinhas brancas de rendas. Chapéus de fitas das mais variadas cores, penas de garça e de guará, miçangas e vidrilhos, espelhos e contas. Tudo matizado, tudo alegre. O retumbão se ensaia.[...]"(SILVEIRA, 1952, p.78). O tempo é de festa, alegria, cores e diversão. As marujas nos seus melhores trajes nas cores da carne e do céu, apaziguados pelos tons de branco. São as penas das aves da região bragantina que são usadas para os enfeites do autêntico e tradicional chapéu da maruja. As vestes suntuosas e de renda, os enfeites, as cores em exagero lembram as misturas das etnias entre africanos e europeus: as blusas de renda e os saiões rodados das sinhás e os colares e as guias multicoloridas das mulheres africanas.

O chapéu carrega em si cada elemento que representa as origens do povo bragantino: as penas favorecem uma representação do índio com seus cocares de uma diversidade de cores e formatos, já as miçangas, vidrilhos e contas favorecem a representação dos escravos, é sabido que em algumas religiões africanas os colares coloridos são utilizados em rituais, para identificar a hierarquia ou até mesmo deuses e entidades. O elemento europeu é representado pelos espelhos, visto que eram provenientes da cultura ocidental e serviram de moeda de troca com os primeiros habitantes brasileiros.

Jorge Ramos, em sua crônica sentimental, evidencia sempre a emoção do bragantino ausente, mesmo longe pertence ao universo da Marujada, elo de identificação com o povo devoto. "O chamado" será o eco de unificação da cultura, o outro se identifica por consignação da memória, afinal tudo perde o sentido, nem a moça mais bonita, nem o cinema, nem as festas, nada poderá tirar o bragantino da sua 
tristeza de saudade: “[...] Em nada. Tudo negro, para ele que se preza de ser bragantino da gema. Amanhece doente. 'Hoje não vou trabalhar. É dia 26 de dezembro'. Pronto e isso basta. É uma sagrada resolução [...]” (RAMOS, 1952, p. 3) Resolve-se não trabalhar, e tudo pode afinal o motivo é sagrado, divino, é louvação ao santo: "É feriado popular, dia do Milagroso Santo do Caeté, Protetor Genuíno de Todos os Bragantinos. São Benedito, o Santo Negro Quituteiro, nesse dia vê-se cercado pela multidão de seus fiéis todos juntos, Bragança em peso, prestando a sua grande homenagem”. (RAMOS, 1952, p. 3) Não se trata de qualquer santo, ou até mesmo qualquer São Benedito, o dia é do característico e importante santo do rio Caeté, aquele que protege todos os bragantinos, que por identificação o louvam, antes de ser o São Benedito, católico, negro e quituteiro é o santo de Bragança. O amor transmutado em devoção e fé passa pelo processo da identidade cultural do povo, a multidão fiel.

Ao lembrar da devoção do povo e da comoção da multidão, o bragantino distante da sua terra, seja ele "de um apartamento ou de um miserável quarto de pensão suburbana. Ou mesmo dentro de um palácio”, ao ver o 26 na folhinha, calendário, fica triste por não partilhar dos momentos de louvação, fechará os olhos e lembrará:

\begin{abstract}
Dia claro, o sol invadindo e banhando toda a extensa terra do Vale do Caeté. Vem surgindo da terra o batuque, o som do tambor, o violino modesto e principalmente a cantilena em coro dos festeiros na Barraca da Santa. É a marujada. A nossa e só nossa marujada. As pretas e as morenas de saiões vermelhos, casaquinhos brancos, que foram guardados um ano, juntamente com a piprioca e o alecrim dentro da mala, o chapéu de pluma de todas as cores, do guará, do pato, aqueles chapéus cheios de espelhinhos, miçangas e outras besteirinhas. (RAMOS, 1952, p. 3)
\end{abstract}

A Marujada das lembranças do bragantino distante está inundada de uma beleza natural, da luz do sol que clareia o rio, as sonoridades, em efeito sinestésico, invadem a memória, o som do batuque e do coro, o cheiro da piprioca e do alecrim das roupas das marujas. A lembrança é sentimental e melancólica, mas feliz de uma marujada da qual se tem posse, por identificação e por devoção: "é nossa". A memória das vestes das marujas, pretas e morenas, a referência clara a Marujada dos escravos, das cores vibrantes, dos chapéus enfeitados, com suas típicas miçangas e seus espelhinhos, o sincrético tom da mistura das culturas e "outras besteirinhas”, são só adereços.

O sincretismo sinestésico é ressaltado: a multidão, os tambores, todos os devotos ao redor do milagroso Santo Preto, como diz o autor, menção intensa da cor, demarcando mais uma vez o elemento negro. Na memória do bragantino tudo fica nítido, pois "um dia assistiu contrito também ao Santo Sacrifício na Igrejinha simples, que se espelha no Rio Caeté, por tantos e tantos anos." A tradição é antiga, e diversas 
gerações de bragantinos já vivenciaram humildemente o "sacrifício" em torno da igreja construída as margens do rio por escravos na época em que o Brasil principiava a colonização, o rio é o espelho da tradição cultural e do tempo.

O rio da "tradição, as danças bragantinas, o lundum, o retumbão," que o bragantino saudoso "tem vontade de largar a cama e descalço, no assoalho do quarto, ouvindo como estão os sons vindos de longe, sair dançando, sozinho, o retumbão e o lundum." A convocação chega a qualquer lugar, o som da lembrança provoca no bragantino a ânsia de está próximo dos seus conterrâneos, de dançar o ritmo que só quem é bragantino conhece bem, é o sentimento de identidade cultural, de pertencer não só a um espaço, mas de partilhar de uma emoção, da "grande confraternização no Vale do Caeté, de todos os bragantinos e o batismo dos que não o são, que se dá nesse dia na barraca da juíza".

Portanto, a caracterização da festa da Marujada como unificadora da cultura bragantina, nas crônicas analisadas, acontecerá em vertentes paralelas, porém em trilhas diferentes a de Lobão da Silveira em sua ideia de expectativa autêntica da vivencia da festividade em todas as suas nuances e a de Jorge Ramos por uma expectativa sentimental que clama a presença através da memória, mais poética e sensível a devoção ao santo.

\section{Os silêncios de uma identidade negra}

Fig.05: Marujas dançam no Museu da Maurjada

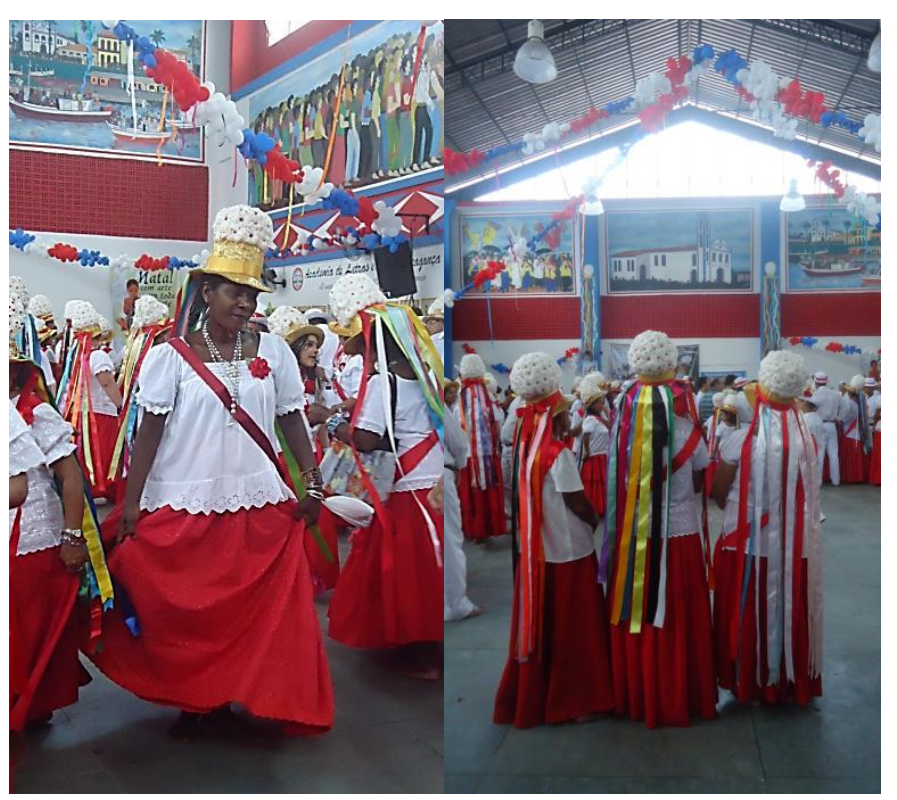

Fonte: Acervo Pessoal. Dezembro de 2012. 
O autor continua elucidando as características da festividade relembra o passado e o demarca como uma época boa. Vejamos o trecho:

[...] A capitoa comanda a turma. Reminiscência do passado. Santa ingenuidade que não faz mal a ninguém. $\mathrm{O}$ intuito vale tudo. É a homenagem a São Benedito. E elas vão passando, a viola tocando, a cuíca roncando, girando, volteiando, tudo para agradar São Benedito. Resto de africanismo. Bragança negróide, disse o poeta Eimar Tavares, um pedaço gostoso do passado. A única tradição que nos resta do passado, desse passado que era tão bom e que sangra saudades no coração da gente. (SILVEIRA, 1952, p. 78)

Os silêncios ecoam neste trecho, é latente a voz que diz para ocultar ao citar o passado, as origens, sempre em frases curtas, diz-se e finaliza-se logo, encerra-se a frase para evitar as contradições, pontuam-se aspectos da tradição originária em poucas palavras, a frase se conclui em silêncio.

Percebemos que sob o comando feminino, marca de uma identidade negra, em suas sociedades matriarcais, a capitoa conduz o elo com o passado, os escravos dos cultos pagãos das religiões afrodescendentes. O autor ressalta a "santa ingenuidade", uma expressão que pode soar irônica, dependendo do contexto em que está situada, no caso, refere-se ao fato da crença e devoção do povo ao culto do santo através de uma mulher que exerce a função de líder, silenciosamente questiona-se tanto o comando o feminino quanto a fé e a devoção do povo à crença ao santo. E reitera que a ingenuidade não é um mau e evidencia a possibilidade do não-dito, abre-se a possibilidade de questionar-se sobre o fato de tratar-se de um ritual católico, mas com nuances de culto pagão africano, devido as origens e reminiscências dos escravos que originaram a devoção ao santo negro. Transparece nessa frase o silêncio, o dizer para ocultar. Constrói-se também neste discurso relações sem opressão, além disso e muito mais forte é dizer que festa é o 'resto de africanismo', com isso, silencia-se a presença de afrodescendente que, mesmo depois da escravidão mantém as marcas da presença negra no Brasil, assim como da história da escravidão. Constrói-se uma memória pelo avesso.

O narrador diz que vale tudo pelo objetivo, a honra a São Benedito, ou seja, as origens africanas, a liderança feminina, a devoção ao santo negro, tudo é apropriado, já que a intenção, pelo menos aparentemente, é louvar um santo católico. Assim, mesmo que os meios de louvação sejam provenientes dos "restos de africanismos" o objetivo é validado, porque os devotos, em sua ingenuidade, não tem conhecimento das origens e mantem-se firmes na devoção cristã, daí o fato de não se ver nenhum mal na louvação ao São Benedito. Esconde-se e silencia-se o fato de uma possível transmutação sincrética de São Benedito arraigado nas origens do ritual. 
Neste ponto questionamos a própria representação da imagem do santo, afinal para alguns rituais africanos as imagens católicas são atribuídas às entidades de cultos africanos, seria São Benedito também uma representação pagã? Daí o culto proveniente da Bragança negróide, "pedaço gostoso do passado", dos rastros de africanismo, como diz o autor.

O ritual das esmolações, os sons, as danças, enfim todas as manifestações culturais que envolvem a Marujada são justificadas por se tratarem de uma homenagem ao São Benedito, como diz o autor: "para agradar São Benedito”. E finaliza o parágrafo, com uma saudade que sangra ao lembrar um passado que era tão bom, a palavra sangrar, utilizada metaforicamente, pode ser o rastro silencioso do passado dos escravos, que sofreram nas torturas causadas por seus senhores. Seria um passado bom, um "pedaço gostoso do passado"? Soaria contraditório, se estivéssemos observando a narrativa por um olhar de um negro, mas aqui se trata de alguém que ainda reproduz o discurso hegemônico da classe dominante. Aqui fica evidente, a marca da autoria e o silenciamento das origens negras em detrimento da manutenção de uma visão histórica que pontua a escravidão como algo natural. Vale ressaltar, que o texto foi publicado em uma revista de grande aceitação na época pelas autoridades do município, e que o autor fazia parte da elite bragantina.

Sendo assim, Lobão da Silveira e Jorge Ramos deixam rastros em suas narrativas que revelam silêncios. Indícios de africanismos de uma nação, que mesmo escravizada sob todas as formas de dominação conseguiu imprimir em suas práticas códigos de resistência que perduram até hoje mesmo que veladamente, por baixo do véu do silêncio.

\section{Considerações finais}

Entre rastros e silêncios, a memória se registra e faz sentido. O próprio texto é um rastro, tudo que se escreve e se inscreve, graficamente ou não, já é por si só um marco instaurado de história, guarda em si sentidos que levam a outros sentidos. Assim como o rastro, o silêncio tem uma importância e é, às vezes, como algo contendo sentidos a serem descobertos que ele se escreve nas narrativas.

Os cronistas e os tempos mudam, mas os rastros mostram que os silêncios perduram e traspassam a história. Portanto, se queremos observar uma tradição cultural secular como a Marujada de São Benedito de Bragança, devemos ressalvar quais são os rastros e os silêncios que se instauram tanto na história quanto nas narrativas literárias. 
Por isso que se torna tão necessário ressaltar as crônicas que foram veiculadas nos jornais e revistas da região, ou pelo menos, aquelas a que temos acesso, no caso a crônica "O Esperado" de Joaquim Lobão da Silveira e "O Chamado" do poeta Jorge Ramos. Só assim, analisaremos as marcas mudas de um período em que ficar calado era a melhor opção.

Assim, os silêncios também são rastros do sentido que se instauram na memória, na história, no discurso, nas narrativas. Logo, cabem-nos percebê-los e analisá-los. Afinal, os traços silenciosos são marcas significantes nas narrativas do passado, que fixam um acontecimento, por vezes silenciados conscientemente, noutras já se encontram incutidos na memória.

\section{Referências bibliográficas}

CARVALHO, G. M. de O. A festa do "Santo Preto": tradição e percepção da Marujada Bragantina. Dissertação (Mestrado) UNB, Brasília-DF, 2010.

CASTRO, E. (org.). Escravos e senhores de Bragança. Belém: NAEA, 2006.

GAGNEBIN, J. M. O rastro e a cicatriz: metáforas da memória. In: GAGNEBIN, J. M. Lembrar escrever esquecer. Ed. 34. São Paulo, 2006, p. 107-118.

NONATO DA SILVA, Dário Benedito Rodrigues. Os Donos de São Benedito: convenções e rebeldias na luta entre o catolicismo tradicional e devocional na cultura de Bragança, século XX. Dissertação (Mestrado) - Centro de Filosofia e Ciências Humanas, Universidade Federal do Pará, Belém, 2006.

ORLANDI, E. P. As formas do silêncio: no movimento dos sentidos. Campinas-SP: UNICAMP, 1997.

POLLAK, M. Memória, Esquecimento, Silêncio. Estudos Históricos. Rio de Janeiro, v. 2, n. 3, 1989, p. 3-15.

RAMOS, Jorge Daniel de Sousa. O Chamado. In: Revista Bragança Ilustrada. Bragança-PA, n. 9-10, 1952, p. 3-8.

ROSÁRIO, Ubiratan. O redespertar do Caeté: Evolução sócio-cultural do município de Bragança, Pará, século vinte. In: Revista Bragança, ano IV, nº 3, março/2006.

ROSÁRIO, Ubiratan. Os escritores da Bragança Ilustrada nas ilusões do pós-guerra. In: Jornal "O Semanário", ano. V. n. 106, 20/03/1999.

SILVA, D. B. da. Os Tambores da Esperança: um Estudo Antropológico sobre a Construção da Identidade na Irmandade do Glorioso São Benedito de Bragança. Belém: Falangola Editora, 1997. 
SILVEIRA, Joaquim Lobão da. O Esperado. In: Revista Bragança Ilustrada. Bragança-PA. n. 9-10, 1952, p. 78.

\section{Notas:}

${ }^{1}$ Pós-graduanda do Mestrado de Linguagens e Saberes na Amazônia, Universidade Federal do Pará, Campus Universitário de Bragança. Bolsista SEDUC/PA. E-mail: larissafontinelle@ yahoo.com.br.

${ }^{2}$ Panfleto distribuído pela Irmandade da Marujada de São Benedito, entre os anos 2008-2010. 